\title{
The Relationship Between Inflation and Gold Price: Evidence From Sri Lanka
}

\author{
S. Anandasayanan (Corresponding author) \\ Senior Lecturer, Dept. of Financial Management, University of Jaffna, Sri Lanka \\ E-mail: sayananakshi@yahoo.com
}

Janani Thevananth

Senior Lecturer, Dept. of Financial Management, University of Jaffna, Sri Lanka

Email: jananithevananth@yahoo.co.in

\author{
A. Mathuranthy \\ Student, MBA /Faculty of Management Studies and Commerce \\ University of Jaffna, Sri Lanka \\ Email: mathu_019@hotmail.com
}

Received: November 2, 2019 Accepted: December 5, 2019 Published: December 9, 2019

doi:10.5296/ijafr.v9i4.15750 ～URL:https://doi.org/10.5296/ijafr.v9i4.15750

\begin{abstract}
Gold is most sacred metal among Sri Lankans due to it security and high demand. Gold is treated as an alternative investment avenue. It is often stated that gold is the best preserving purchasing power in the long run. Gold investment can also be used as a hedge against inflation and currency depreciation. Therefore, investors are showing interest in investing in the gold due to economic vulnerability. From an economic and financial point of view, movements in the price of gold are both interesting and important. It cannot be denied that gold price is stable all the time and has minimal fluctuation for economic volatility and financial condition. The price of gold is affected by various factors like inflation, crude oil, exchange rate etc. But gold prices are fluctuated by inflation significantly. Gold prices control the inflation instability. Therefore, deep understanding of the relationship between
\end{abstract}


inflation and gold price is prerequisite. The ultimate objective of the study is to explore the relationship between inflation and gold price. The dependent variable is gold price which is measured by Sri Lanka rupee per Troy ounce meanwhile the independent variable is inflation which is measured by wholesale price index. 240 monthly observations from January 1999 to December 2018 were used in the study. Unit root test, correlation analysis, ordinary least square regression analysis, granger causality test and normality tests are employed for analysing data. The empirical results have found strong and positive correlation between inflation and gold price. The results of regression analysis revealed that inflation significantly impacts on gold price. Unidirectional relationship was found between gold price and inflation.

Keywords: Gold price, Inflation and wholesale price index

\section{Introduction}

\subsection{Background of the Study}

Gold price is one factor that represents the economic wealth of a country. It is the most leading indicators of the economic development. The economy of a country is prosperous when the gold prices are low. Asian people often buy gold to use as a hedge or a direct investment. Sri Lanka is one of the country that has largest consumers of gold in worldwide. There is a surge in jewellery demand among Sri Lankans traditionally, especially among Sri Lankan Tamils during wedding seasons that is from July to September. This trend often leads to increase in gold prices. The demand for gold is interwoven among Sri Lankans due to tradition and willingness for gold. Further, they are interested in buying gold to protect themselves from uncertainties. Usually the price of gold is affected by various economic factors. When the rate of inflation goes up, the value of currency goes down therefore people purchase gold more. The gold prices are higher during inflationary period. Inflation is the rise in prices of goods and services. It affects the purchasing power of people in the country. This is known as price inflation. According to Bhunia, and Mukhuti, 2013, gold price rises when there is a bearish outlook of the economy or some uncertainty over the future. Various studies have attempted to figure out the association between gold price and Inflation. Tufail and Batool, (2013) have proved that gold prices can significantly impact on the inflation.

Investors opt to invest in the share market as well as in the gold, to reduce or eliminate the systematic risk. It is also considered as an insurance against risk to invest in gold as well as gold is used as a hedging tool (Bhunia, 2013). This is because gold is seen as store of value, while the stock market is only seen as a return of value (Shahzadi, 2016). These characteristics of the gold and stock market are what drives the investor's behaviour when investing in gold or stocks. Hence, it can be concluded that gold tends to have some kind of a relationship with the stock market that may be affected by different economic variables. It is difficult to make predictions about gold prices due to the global economic chaos. It is also riskier for the investors to invest in the stock exchange of developing countries like Sri Lanka than purchasing gold. The domestic gold prices increase as demand for gold is always high. As economic uncertainty, inflation and market volatility increases, interest in gold as a hedge will also increase. 


\section{Gold Monthly Price - Sri Lanka Rupee per Troy ounce}

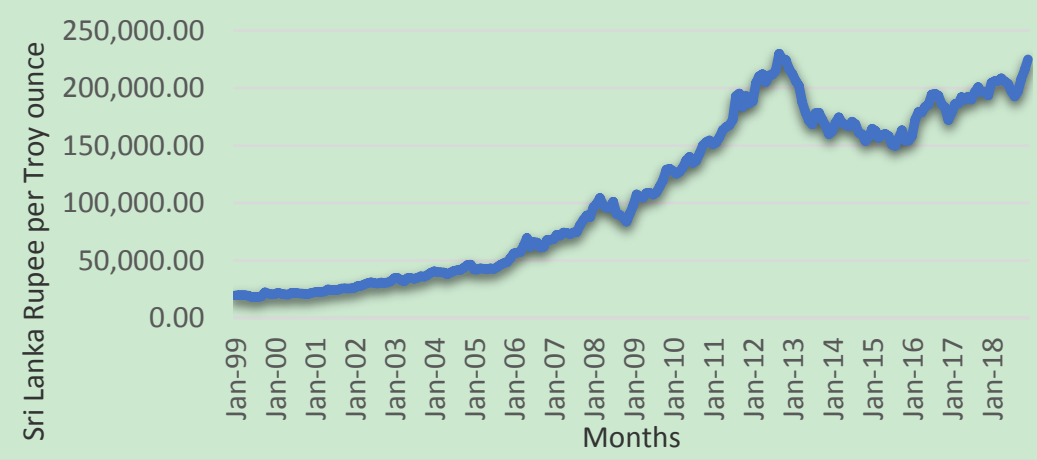

Figure 1. Monthly price movement of gold in Sri Lankan market

Source: www.cbsl.gov.lk

Figure 1 shows the monthly price movement of gold in Sri Lankan market. Though there were decreases in the price of gold in Sri Lanka, overall it is continuously increasing due to its tremendous demand among Sri Lankans due to its security. Gold has the ability to sustain its liquidity level during critical time especially during high inflation period or political instability time. People are holding gold to build a diversified portfolio. The price of gold is influenced by numerous factors and inflation is one of them.

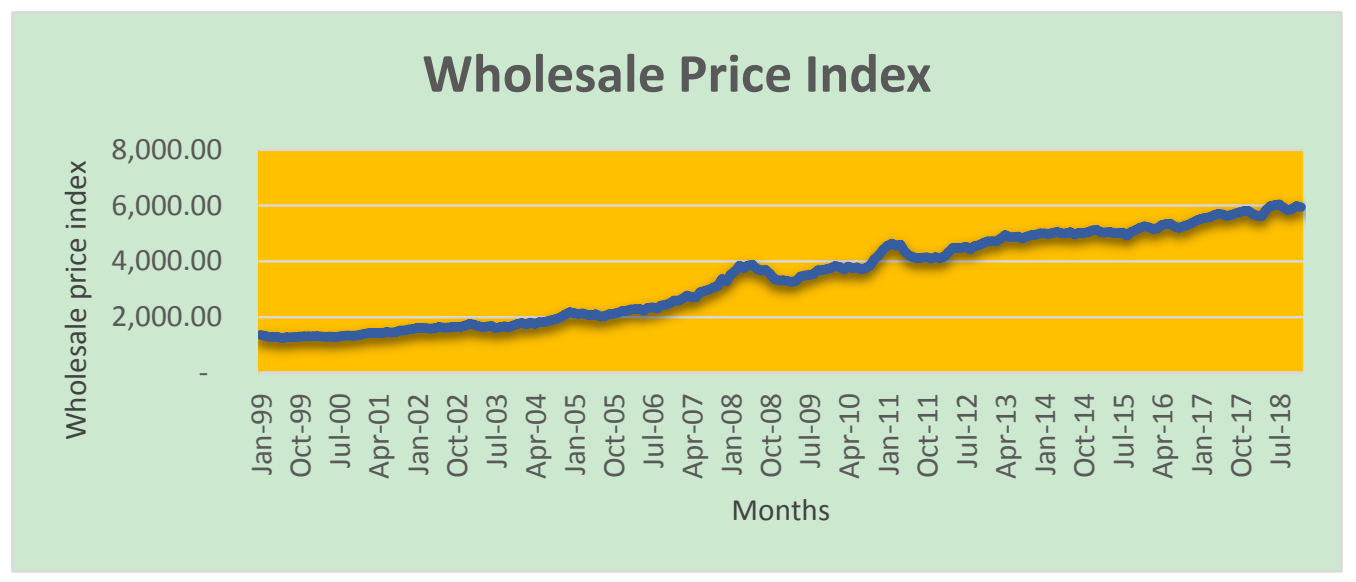

Figure 2. Monthly movement of wholesale price index

Source: Department of census \& statistics

As shown in Figure 2, wholesale price index shows an upward trend though it has been experiencing fluctuations. 


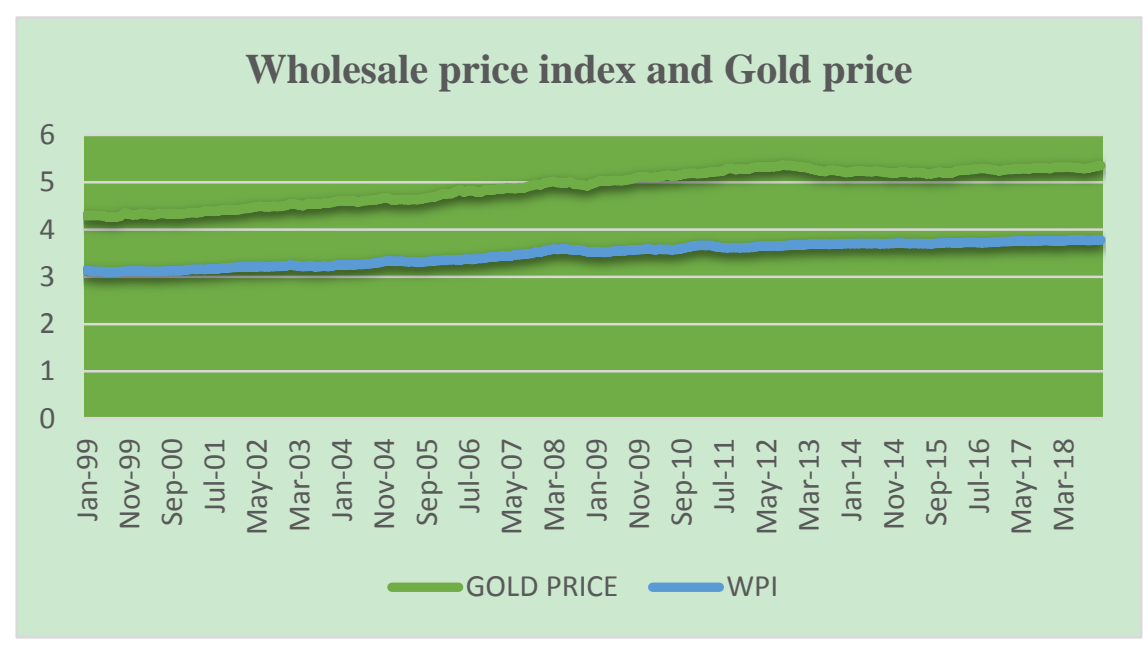

Figure 3. Monthly movement of inflation and wholesale price index

The log value of gold price and inflation is presented in Figure 3. It is obvious that the gold price is higher than inflation (wholesale price index) but the difference between two variables is very low.

\subsection{Research Problem}

The importance of gold has been rising as a result of dwindling economic growth in Sri Lanka therefore, clearly understanding the relationship between inflation and gold price and the effect of inflation on gold price is inevitable for better economic growth. Previous studies have found contradictory results between inflation and gold price, namely, both positive and negative correlation were found. There is requirement to confirm whether there is positive association between inflation and gold price or not. Further, lack of studies was conducted in Sri Lanka which has largest gold customers. Figuring out exactly what relationship does exist between gold price and inflation is important. If inflation is influencing the price of gold in Sri Lanka, it is crucial to examine to what extent inflation impacts on gold price. Clarifications of the correlation between variables enable investors to make right choice when they invest. The following questions will be investigated in this study.

To what extent does inflation impact on gold price?

\subsection{The Objective of the Study}

The objective of this research is to find out the relationship between inflation and gold price.

\section{Literature Review}

The chapter literature review is based on previously conducted studies related to gold price and inflation.

Afsal and Haque (2016) carried out an investigation on market interactions in gold and stock markets: evidences from Saudi Arabia. The price movements in gold market were considered to identify the non-linear dependencies with stock market in the Saudi Arabia. Univariate and multivariate models of generalized autoregressive conditional heteroskedasticity (GARCH) 
class were used to analyse the results in this study. Initially, the work used GARCH specification to detect the persistence level of volatility. A series of models were used to study leverage effect, spill-over pattern, risk-premium effects, absolute returns and power transformation factors, etc., Finally, diagonal Baba, Engle, Kraft and Kroner specification was employed to determine the contagion effect between gold and stock markets. The research findings that a dynamic relationship between gold and stock market does not exist.

Sindhu (2013) examined a study on impact of selected factors on the price of Gold. Exchange rate of US dollar with INR, Crude oil prices, repo rate and inflation rate were taken into consideration. Each factor is studied with price of gold. The research findings indicated that there is an inverse relationship between the US\$ and gold prices. The crude oil prices have an impact on the gold prices. Gold prices and repo rates are interdependent. Gold prices and inflation have positive association.

Pitigalaarachchi, Jayasundara and Chandrasekara (2016) examined the modelling and forecasting Sri Lankan gold prices. Data from January 2005 to May 2014 which consists of, 113 observations were taken for the study. The study found that identified two models are suitable to forecast gold prices in Sri Lanka for short time periods. When the forecasting time period is increasing percentage errors from the VAR model are higher than ARIMA model. It can be concluded that the ARIMA model is more appropriate to forecast gold prices in Sri Lanka than the fitted VAR model.

Ibrahim (2014) investigated the determinants of gold prices in Malaysia. Multiple Linear Regression Model was employed to determine the significant relationship between dependent and independent variables, covering data for 10-year period which are from 2003 until 2012. The price of gold was the dependent variable and crude oil prices, inflation rates and exchange rates were independent variables. The empirical results have revealed that there is negative and significant association between inflation rates and exchange rates on gold prices, while a crude oil price is positively significant.

Tripathy (2016) conducted a research on dynamic relationship between gold price and stock market price in India by using monthly time series data from July 1990 to April 2016. Unit root test, Correlation test, Granger causality test and Johansson's co-integration test were employed to evaluate their relationship. The research found that there is no causal relationship exist in between gold price and stock market price in the short run. However, gold price and stock market price are co-integrated indicating long-run equilibrium relationship between them, and they move together. The CUSUM test also confirmed the existence of long run relationship between gold and stock market price and exhibits the stability of coefficient. The stock market price can be used to predict the gold price. The investigation suggested that integration between gold and stock market price necessitates the need for global investors to follow portfolio stock selection strategy to add value from investments in India. However, the scope of these opportunities is limited in the short-run.

Blose (2010) examined on the gold prices, cost of carry, and expected inflation by employing unexpected changes in the consumer price index (CPI) and the results indicated that CPI does not affect gold spot prices. The findings revealed that investors anticipating changes in 
inflation expectations should design speculation strategies in the bond markets rather than the gold markets. Additionally, investors cannot determine market inflation expectations by examining the price of gold.

Subarna and Ali investigated the relationship between gold prices and Bahrain stock exchange. The data from Feb 2001 to Jan 2014 was used and EARCH model was employed in the study. The variables were stock exchange as the independent variable and gold prices, oil prices as the dependent variables, they had shown the results that there is significant relationship between Bahrain stock exchange and gold prices. They had suggested that investors should invest in the gold rather than stock exchange.

Venkatraja (2014) investigated the relationship between the Indian stock market performance (BSE Sensex) and five macroeconomic variables, namely, index of industrial production, wholesale price index, gold price, foreign institutional investment and real effective exchange rate. The sampling period was from April 2010 to June 2014 using monthly data. The multiple regression technique was employed. The research findings indicated that the wholesale price index, index of industrial production, foreign institutional investment and real effective exchange rate have a high degree of positive influence on the Sensex. It was also found that Sensex is inversely influenced by changes in the gold price.

Sadorsky, researched the relationship between gold prices and Egypt stock exchange. Data from Feb 2007 to Jan 2015 was collected and the ARCH model was employed. The variables were stock exchange as the independent variable and gold prices, and oil prices as the dependent variables. Study found that there is significant relationship between Egypt stock exchange and gold prices. They had suggested that investors should invest in the gold rather than stock exchange.

Safi and Soytas Analyzed that the relationship between gold prices and Bangladesh stock exchange. Data was collected from Feb 2001 to Jan 2014 and utilized the VECM model. Stock exchange as the independent variable and gold prices, and oil prices as the dependent variables and the findings had shown that there is significant relationship between Bangladesh stock exchange and gold prices.

Mishra, Das and Mishra (2010) studied the gold price volatility and stock market returns in India. The results indicated that the gold prices Granger-causes stock market returns and stock market returns also Granger-causes the gold prices in India during the sample period.

Smith (2001) in a study on US using cointegration and Granger Causality found a slightly inverse relation between the gold price and stock prices. In a related study on Europe and Japan, Smith (2002) using cointegration and Granger Causality found that in the short term there was a negative relation between gold prices and the stock market in the short run, but in the long term the relationship was not significant.

Contuk, Burucu and Gungor (2013) examined the effect of fluctuations in gold prices on ISE 100 index using daily prices and the index data from January 2009 to December 2012. The raw data has been converted into earnings yields and analyzed. The research findings obtained from GARCH modeling show that gold and stock exchange yields have been 


\section{Mll Macrothink}

International Journal of Accounting and Financial Reporting

ISSN 2162-3082

2019, Vol. 9, No. 4

affected both by their own shocks and by shocks of each other. Chung, Kwon and Tai Shin (1999) examined the relationship between gold prices and Japan stock exchange. The sampling period was from Feb 2004 to Jan 2014 and utilized the VAR model. The used variables were stock exchange as the independent variable and gold prices and oil prices as the dependent variables. The study had shown that there is significant relationship between Japan stock exchange and gold prices.

\section{Methodology}

\subsection{Data Collection and Sampling Method}

Secondary data collection is the data collection method employed in this study. The sampling period was from January 1999 to December 2018 which consists of 240 monthly observations. The data of both gold price has been collected from Central Bank of Sri Lanka and wholesale price index was gathered from department of census and statistics. Log value of dependent and independent variables are used for better understanding.

\subsection{Conceptual Framework}

After reviewing the literature, the following conceptual model is formulated to explore the relationship between inflation and gold price.

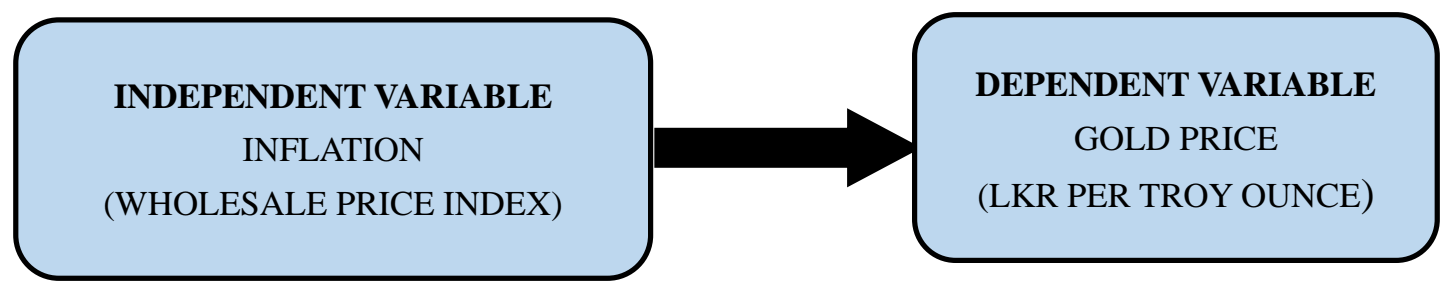

Figure 4. Conceptual model

Source: Developed by researcher

The inflation(wholesale price index) is considered as the independent variable and gold price (LKR per troy ounce) is considered as the dependent variable to explore the relationship between inflation and gold price.

\subsection{Definition of Variables}

\subsubsection{Inflation (Wholesale Price Index)}

An increase in prices is known as inflation that is, the increase in the cost of living as the price of goods and services rise. Inflation leads to a decline in the value of money. The inflation rate is the annual percentage change in the price level. Both consumer price index (CPI) and Wholesale price index (WPI) are used to measure the inflation but wholesale price index (WPI) has been used as the proxy for inflation in this study. It is widely used by various researchers, governments, banks, and industries because it examines the price movements in most comprehensive manner. 


\section{MlMacrothink}

International Journal of Accounting and Financial Reporting

ISSN 2162-3082

2019, Vol. 9, No. 4

\subsubsection{Gold Price}

Gold is has become a substitute investment avenue among Sri Lankan investors. The necessity of gold has become high due to the financial crisis in the present economic world. The monthly gold price is used in the study which was collected from Central Bank of Sri Lanka. Sri Lanka rupee per troy ounce was used to measure the gold price.

\subsection{Hypotheses of the Study}

Based on the conceptual model the following hypotheses are formulated.

$\mathrm{H}_{1}$ : There is a significant relationship between inflation and gold price.

$\mathrm{H}_{2}$ : Inflation significantly impacts on the gold price.

\section{Results and Discussion}

\subsection{Descriptive Statistics}

Descriptive statistics is the primary data analysis method that is used to describe the basic components of both dependent and independent variables. The descriptive statistics include means, maximum, minimum, standard deviation, skewness and kurtosis.

Table 1. Results of descriptive statistics

$\begin{array}{lcc} & \text { WPI } & \text { GOLD PRICE } \\ \text { Mean } & 3.479319 & 4.910992 \\ \text { Median } & 3.556312 & 5.011718 \\ \text { Maximum } & 3.780841 & 5.361524 \\ \text { Minimum } & 3.092335 & 4.260224 \\ \text { Std. Dev. } & 0.226144 & 0.360437 \\ \text { Skewness } & -0.323670 & -0.417031 \\ \text { Kurtosis } & 1.574790 & 1.651649 \\ & & \\ \text { Jarque-Bera } & 24.50273 & 25.13709 \\ \text { Probability } & 0.000005 & 0.000003 \\ & & \\ \text { Sum } & 835.0366 & 1178.638 \\ \text { Sum Sq. Dev. } & 12.22278 & 31.04960 \\ & & \\ \text { Observations } & 240 & 240\end{array}$

Table 1 clearly represents the descriptive statistics of both independent and dependent variables in which 240 monthly observations from January 1999 to December 2018 have been included in the study. The mean of wholesale price index is $3.479319,3.780841$ is the maximum, 3.092335 is the minimum, 0.226144 is Standard deviation, -0.323670 is skewness, and 1.574790 is the kurtosis meanwhile the mean, maximum, minimum, standard deviation, skewness and kurtosis of gold price are 4.910992, 5.361524, 4.260224, 0.360437, -0.417031, and 1.651649 respectively.

\subsection{Correlation Analysis}

The ultimate objective of employing correlation analysis is to explore the relationship between variables. It was carried out in this research study to find out the relationship between inflation and gold price. 


\section{Macrothink}

Table 2. Results of correlation analysis

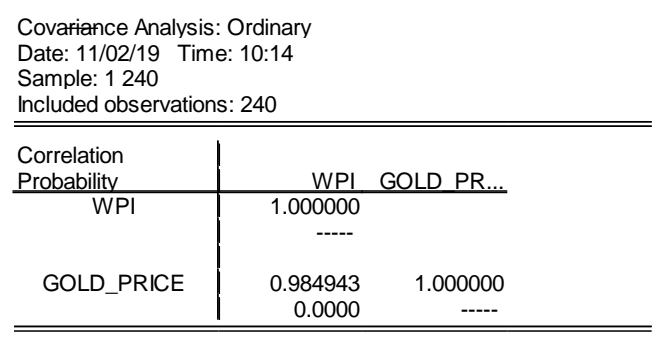

Table 2 depicts the results of correlation analysis. The inflation is positively and significantly correlated with gold price with the estimated coefficient value of 0.984943 and $\mathrm{p}$ value of 0.0000 which is significant at 1 per cent significant level. Then $\mathrm{H}_{1}$ is supported. Therefore, there is positive relationship between inflation and gold price in Sri Lanka. When the inflation is high, the prices of commodities like food, energy and clothing will also be high. The currency also goes down during high inflationary period, therefore people tend to hold money in the form of gold. The results of correlation analysis clearly indicate that gold has been used as a tool to hedge against inflationary conditions in Sri Lanka.

\subsection{Results of Regression Analysis}

The aim of employing regression analysis is to determine how much of the variance in the dependent variable is predicted by the independent variable and which of the independent variables is most predictive. Regression analysis is employed to measure the impact of inflation on gold price in Sri Lanka.

Table 3. Results of regression analysis

\begin{tabular}{|c|c|c|c|c|}
\hline \multicolumn{5}{|c|}{$\begin{array}{l}\text { Dependent Variable: GOLD_PRICE } \\
\text { Method: teast-Squares } \\
\text { Date: } 11 / 02 / 19 \text { Time: } 10: 15 \\
\text { Sample: } 1240 \\
\text { Included observations: } 240 \\
\end{array}$} \\
\hline Variable & Coefficient & Std. Error & t-Statistic & Prob. \\
\hline $\begin{array}{l}c \\
\text { WPI }\end{array}$ & $\begin{array}{r}-0.550966 \\
1.569835 \\
\end{array}$ & $\begin{array}{l}0.062274 \\
0.017861\end{array}$ & $\begin{array}{r}-8.847475 \\
87.89298 \\
\end{array}$ & $\begin{array}{l}0.0000 \\
0.0000 \\
\end{array}$ \\
\hline $\begin{array}{l}\text { R-squared } \\
\text { Adjusted R-squared } \\
\text { S.E. of regression } \\
\text { Sum squared resid } \\
\text { Loq likelihood } \\
\text { F-statistic } \\
\text { Prob(F-statistic) }\end{array}$ & $\begin{array}{l}0.970112 \\
0.969987 \\
0.062443 \\
0.927997 \\
326.0986 \\
7725.175 \\
0.000000\end{array}$ & \multicolumn{2}{|c|}{$\begin{array}{l}\text { Mean dependent var } \\
\text { S.D. dependent var } \\
\text { Akaike info criterion } \\
\text { Schwarz criterion } \\
\text { Hannan-Quinn criter. } \\
\text { Durbin-Watson stat }\end{array}$} & $\begin{array}{r}4.910992 \\
0.360437 \\
-2.700822 \\
-2.671816 \\
-2.689135 \\
2.105426\end{array}$ \\
\hline
\end{tabular}

As shown in the Table 3, the R-squared is 0.970112, the adjusted R-squared is 0.969987 which endorses that nearly 97 per cent of the variation in the gold price is explained by the independent variable, inflation. The coefficient for independent variable (1.569835) gives the size of the effect that variable is having on the dependent variable. $\mathrm{P}$ value of wholesale price index is 0.0000 which is significant at 1 per cent significant level. $\mathrm{H}_{2}$ is supported. It can be concluded that inflation is significantly impacting on gold price.

\subsection{Unit Root Test}

Primarily the unit root test is carried out in this research study to examine whether a time series variable is stationary or non-stationary and possesses a unit root. Stationary time series are 


\section{Ml Macrothink}

International Journal of Accounting and Financial Reporting

ISSN 2162-3082 2019, Vol. 9, No. 4

de-trended series, without periodic fluctuations. The stationary is checked by using Phillips-Perron unit root test in this study.

Table 4. Results of Phillips-Perron unit root test

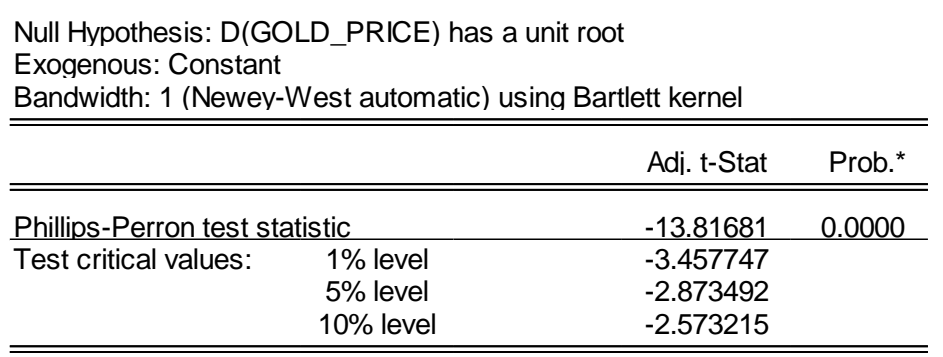

*MacKinnon (1996) one-sided p-values.

The Phillips-Perron statistic value is -13.81681 and the associated one-sided p-value is 0.0000 . In addition, E-Views reports, the critical values at the $1 \%, 5 \%$ and $10 \%$ levels. The statistic value here is greater than the critical values so that we do not reject the null at conventional test sizes. Therefore, gold price is stationary at first difference.

Table 5. Results of Phillips-Perron unit root test

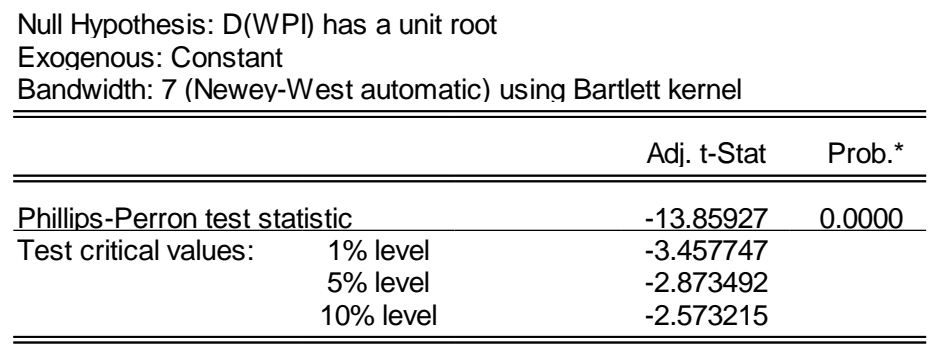

*MacKinnon (1996) one-sided p-values.

The Phillips-Perron statistic value is -13.85927 and the associated one-sided $p$-value is 0.0000 . The statistic value here is greater than the critical values so that we do not reject the null at conventional test sizes. Therefore, inflation (wholesale price index) is stationary at first difference.

\subsection{Granger Causality Test}

Granger causality is a statistical concept of causality that is based on prediction. It is used to determine whether one time series is useful in forecasting another. It also seek the direction of causality between variables.

Table 6. Results of granger causality

Pairwise Granger Causality Tests
Date: $11 / 02 / 19$ Time: $10: 19$
Sample: 1240
Lags: 2


As shown in Table 6, the null hypothesis is gold price does not granger cause to wholesale price index. The $\mathrm{p}$ value is 0.0058 which is less than $0.05 \mathrm{so}$, null hypothesis can be rejected. We can conclude that gold price granger causes to wholesale price index. Hence, there is unidirectional relationship between gold price and inflation.

\section{Conclusion}

The paper examines the relationship between inflation and gold price by using monthly data from January 1999 to December 2018. Correlation analysis, regression analysis, unit root test, and granger causality test have been carried out to analyse the data. The research findings indicate that there is strong and positive association between inflation and gold price. The regression analysis showed that inflation significantly impacts on gold price and Granger causality found that there is unidirectional relationship between gold price and inflation. The similar results have also been found in study done by Bhunia \&Mukhuti (2013) and Shahzadi, (2016). Purchasing gold during high inflationary period is more advisable than investing on share market.

\subsection{Contribution of the Study}

Sri Lankan managers, investors, and economic agents are keen to understand the relationship between inflation and gold price when they make investment decisions. Studying about the factors that affect gold price is prerequisite to promote economic prosperity. Gold has been used as a platform to make investment and it is also good to save money in the form of gold due to its increasing demand. The ultimate intention of this study is to figure out exactly what relationship exists between inflation and gold price because investors are willing to invest in assets that have less risk. This clarification would be beneficial for both national and international investors whether to invest on gold or not

\section{References}

Afsal, E., \& Haque, M. (2016). Market interactions in gold and stock markets: Evidence from Saudi Arabia. International Journal of Economics and Financial Issues, 6(3), 1025-1034.

Basher, S. A., \& Sadorsky, P. (2006). Oil price risk and emerging stock markets. Globel Finance Journal, 17, 224-251.

Bhunia, A., \& Mukhuti, S. (2013). The impact of domestic gold price on stock price indices-an empirical study of Indian stock exchanges. Universal Journal of Marketing and Business Research, 2(2), 60-63.

Blose, L. (2010). Gold Prices, Cost of Carry, and Expected Inflation. Journal of Economics and Business, 62, 35-47.

Kwon, C. S., \& Shin, T. S. (1999). Cointegration and Causality between Macroeconomic Variables and Stock Markets Returns. Globel Finance Journal, 10, 71-81.

Mishra, P. K., Das, J. R., \& Mishra, S. K. (2010). Gold Price Volatility and Stock Market Returns in India. American Journal of Scientific Research, 9, 47-55. 


\section{Macrothink}

International Journal of Accounting and Financial Reporting

ISSN 2162-3082 2019, Vol. 9, No. 4

Pitigalaarachchi, A., Jayasundara, D., \& Chandrasekara, V. (2016). Modeling and Forecasting Sri Lankan Gold Prices. International Journal of Sciences: Basic and Applied Research (IJSBAR), 27, 247-260.

Safi, R., \& Soytas, U. (2006). The Relationship between Stock Returns, Crude Oil Prices, Interest Rates, and Output: Evidence from a Developing Ecomomy. The Emperical Economics Letters.

Samanta, S. K., \& Zadeh, A. H. M. (2012). Co-Movement of Oil, Gold, the US Dollar, and Stocks. Modern Economy, 3, 111-117.

Shahzadi, C. (2016). Gold and oil prices versus stock exchange: A case study of Pakistan. Journal of Business Economics and Management, 10(4), 349-360.

Sindhu. (2013). A study on impact of select factors on the price of Gold. IOSR Journal of Business and Management, 8, 84-93.

Smith, G. (2001). The price of gold and stock price indices for the United States. Retrieved from http://www.spdrgoldshares.com/media/GLD/file/Gold\&USStockIndicesDEC200120fina.pdf

Smith, G. (2002). London gold prices and stock price Indices in Europe and Japan. Retrieved from http://www.spdrgoldshares.com/media/GLD/file/GOLD\&EUJPStockIndicesFeb2002.pdf

Tripathy, N. (2016). A Study on Dynamic Relationship between Gold Price and Stock Market Price in India. European Journal of Economics, Finance and Administrative Sciences.

Tufail, S., \& Batool, S. (2013). An Analysis of the Relationship between Inflation and Gold Prices: Evidence from Pakistan. The Lahore Journal of Economics, 18(2), 1-35.

Venkatraja, B. (2014). Impact of Macroeconomic Variables on Stock Market Performance in India: An Empirical Analysis. International Journal of Business Quantitative Economics and Applied Management Research, 1(6), 71-85.

\section{Copyright Disclaimer}

Copyright for this article is retained by the author(s), with first publication rights granted to the journal.

This is an open-access article distributed under the terms and conditions of the Creative Commons Attribution license (http://creativecommons.org/licenses/by/4.0/) 